\title{
Estimation of the metabolic rate by assessing carbon-13 turnover in broiler tissues using the stable isotope technique
}

\author{
V.C. Pelícia ${ }^{\mathrm{a}, *}$, P.C. Araujo ${ }^{\mathrm{b}}$, F.G. Luiggi ${ }^{\mathrm{b}}$, A.C. Stradiotti ${ }^{\mathrm{b}}$, J.C. Denadai ${ }^{\mathrm{a}}$, J.R. Sartori ${ }^{\mathrm{b}}$, \\ P.D.G. Pacheco ${ }^{\mathrm{b}}$, L.C. Dornelas ${ }^{\mathrm{b}}$, E.T. Silva ${ }^{\mathrm{a}}$, C.R. Souza-Kruliski ${ }^{\mathrm{a}}$, G.E.M. Pimenta ${ }^{\mathrm{b}}$, C. Ducatti $^{\mathrm{a}}$ \\ a Centro de Isótopos Estáveis, Instituto de Biociências de Botucatu, UNESP - Univ Estadual Paulista, Campus de Botucatu, São Paulo, Brazil

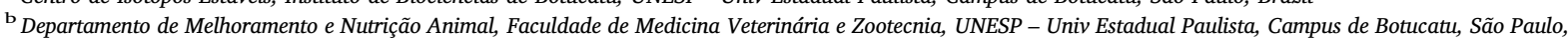 \\ Brazil
}

\section{A R T I C L E I N F O}

\section{Keywords:}

Carbon isotope

Half-life

Metabolism

Poultry

Turnover

\begin{abstract}
A B S T R A C T
The aim of this study was to estimate the metabolic rate of broiler tissues by assessing carbon turnover in different growth phases by using the stable isotope technique and by evaluating the natural changes in Carbon$13\left({ }^{13} \mathrm{C}\right)$ between C3 and C4 cycle plants. Six-hundred 1-day-old broiler chicks were divided into six groups and subjected to dietary changes containing different isotopic values at 7, 14, 21, 28, and 35 days of age. Birds of Group 1 received diets composed predominantly of $\mathrm{C}_{3}$ cycle plants shortly after accommodation, while birds of other groups remained predominantly fed with $\mathrm{C}_{4}$ diet. The diet of Group 2 was mainly replaced by $\mathrm{C}_{3}$ diet on the 7th day of age. Group 3 started to receive $C_{3}$ diet on the 14th day of age, whereas the diet of Group 4 was replaced on the 21st, Group 5 on the 28th. In Group 6, the substitution occurred on the 35th day of age. Samples of the pectoral muscle, keel, tibia, legs muscle, intestinal mucosa, blood, plasma, and feathers were collected. Carbon isotope ratios were determined by mass-spectrometry of isotope ratios. To measure the speed of carbon substitution after a set interval (turnover), a time exponential function was employed and obtained by exponential equations of the first order calculated with Minitab ${ }^{\varpi} 16$ software. The carbon half-life varied from 1.78 to 8.20 days for the pectoral muscle, from 1.91 to 12.24 days for the keel, from 2.32 to 10.71 days for the tibia, from 1.87 to 9.43 days for the leg muscle, from 0.8 to 1.58 days for the intestinal mucosa, from 0.64 to 1.71 days for the plasma, from 2.61 to 11.07 days for blood, and from 1.84 to 28.41 days for the feathers during the total growth phase. With the exception of tibia and blood, all other tissues presented a high metabolic rate in the first week of the broilers' life. The metabolic rate of tissues is faster in younger animals, and the metabolism slows down as the broilers get older. The metabolic rates in the pectoral muscle, keel, tibia, and feathers decreased with age, whereas those of the plasma and intestinal mucosa were high in all evaluated periods; thus, these tissues can be used to study traceability of feed at all stages of the broilers' life.
\end{abstract}

\section{Introduction}

The stable carbon isotopes technique was initially used in geological and archeological studies (Jones et al., 1979; Tieszen et al., 1979; Boutton et al., 1980). However, it has been lately increasingly and continuously applied in agricultural, ecological, and physiological research as an alternative technique in studies on nutrient digestion, absorption, and metabolism of humans and animals, as well as to identify and to determine the origin of plant and animal products (Gannes et al., 1998). This method is based on the fact that $\mathrm{C}_{3}$ and $\mathrm{C}_{4}$ plants possess distinctly different ${ }^{13} \mathrm{C} /{ }^{12} \mathrm{C}$ ratios due to fractionation during photosynthetic carbon fixation (Smith and Epstein, 1971;
O'Leary, 1981). The values of isotope ratios were expressed in delta $\left(\delta^{13} \mathrm{C}\right)$. The $\delta^{13} \mathrm{C}$ values of most $\mathrm{C}_{3}$ plants range from $-24 \%$ to $-34 \%$ o while most $\mathrm{C}_{4}$ plants have $\delta^{13} \mathrm{C}$ values which lie between $-6 \%$ and -19\%o (Smith and Epstein, 1971). Thus, the stable carbon isotopes technique has been successfully used to test the authenticity and the quality of several products, such as orange juice (Bricout and Koziet, 1987; Koziet, 1993), wine (Martin et al., 1988), honey (Brookes et al., 1991; White et al., 1998) and dairy products (Rossmann et al., 2000; Manca et al., 2001). The difference of $\delta^{13} \mathrm{C}$ values between these plants is large enough so that the relative amounts of $\mathrm{C}_{3}$ and $\mathrm{C}_{4}$ plants eaten by an animal can be determined from the $\delta^{13} \mathrm{C}$ value of its carbon (DeNiro and Epstein, 1978), enabling analysis of turnover of stable isotopes in

\footnotetext{
Abbreviation: AOI, animal-origin ingredients; IRMS, isotope ratio mass spectrometer; PDB, PeeDee Belemnite

* Corresponding author.

E-mail address: vcpelicia@yahoo.com.br (V.C. Pelícia).
} 
animal tissues (Tieszen et al., 1983; Hobson and Clarck, 1992, 1993; Hobson, 1995; Hobson and Bairlein, 2003; Ayliffe et al., 2004; Buchheister and Latour, 2010; Oppel and Powell, 2010). More recently, this technique has been used in traceability studies of AOI in poultry feed via tissue analysis (Carrijo et al., 2006; Oliveira et al., 2010; Denadai et al., 2008; Sernagiotto et al., 2013) or identify the origin of a food (Rock, 2012). Furthermore, this technique has been used to evaluate the effect of natural additives, alternative to APE, on the structure of the intestinal mucosa. This was performed by assessing the tissue turnover, given the estimated speed of mucosal regeneration or development (Pelícia et al., 2011).

For traceability, the tissue chosen should reflect the recent diet of the animal and should be able to detect signs in isotopic assimilation of the ingredients to be traced, even if this was supplied during a single earlier growth phase of the animal only.

In the body, slow tissue metabolism can preserve the initial isotope signal from the diet for longer, thus enabling animal-origin ingredients (AOI) detection in poultry after slaughter, and sometimes when provided at an early phase. Conversely, tissues presenting a faster metabolism (in which the isotope signal from the diet is replaced more quickly) may enable AOI detection during the final phases of development, thus reflecting the importance of evaluating metabolic renewal rates or turnover of different tissues and stages of broilers growth. However, to develop these lines of research, further studies would be required to improve the knowledge of isotopic assimilation of organic matter in different bird' tissues and growth phases.

Ducatti et al. (2014) assessed ${ }^{13} \mathrm{C}$ turnover in pectoral muscle, keel, tibia, and liver to obtain physiological information that would be essential for traceability studies. However, the time of assessment and tissue harvest was not sufficient for these tissues to achieve a balanced level of carbon isotope exchange. The authors suggested that new studies should be carried out that increased the evaluation time to confirm the half-lives of stable isotopes. Therefore, the aim of this study was to estimate the metabolic rate via carbon turnover in pectoral muscle, legs muscle, keel, tibia, intestinal mucosa, blood, plasma, and feathers from broiler wings at different growth stages, using natural differences in ${ }^{13} \mathrm{C}$ existing between plants with distinct photosynthetic cycles $\left(\mathrm{C}_{3}\right.$ and $\left.\mathrm{C}_{4}\right)$.

\section{Material and methods}

\subsection{Birds, diets and experimental design}

The survey was conducted at the Laboratory of Avian Nutrition of Faculdade de Medicina Veterinária e Zootecnia, UNESP, Botucatu Campus, São Paulo, Brazil, and all studies were approved by the Ethics Committee for Animal Experimentation (Protocol No 78/2009 - CEEA).

Six-hundred 1-day-old male Cobb broiler chicks were distributed in a completely random design into six groups (named G1, Group 1; G2, Group 2; G3, Group 3; G4, Group 4; G5, Group 5 and G6, Group 6). Each experimental unit comprised 25 birds $\left(8.3\right.$ birds $\left./ \mathrm{m}^{2}\right)$. Birds were housed in an experimental shed divided into twenty-four floor pens of $3 \mathrm{~m}^{2}$. Pens were equipped with hanging drinkers and tubular feeders. Feed and water were offered ad libitum during the entire experimental period. Temperature and ventilation were controlled manually by managing the rearing house lateral curtains.

The rearing period was divided into five phases (pre-starter: 0-7 days, starter: 8-21 days, grower: 22-35 days, finisher 1: 36-62 days, and finisher 2: 63-98 days of age). The food was formulated and adapted in accordance with the tables provided by Rostagno et al. (2011) for nutritional requirements. To reduce variation in the isotopic signal of diets supplied in each growth phase, their concentrations were adjusted where necessary with the addition of rice or corn (Table 1).

The chicks were obtained from breeder hens that received diets predominantly composed by grains of photosynthetic cycle $\mathrm{C}_{4}$ plants (based on corn and soybeans). At birth, they presented isotopic values of Carbon-13 in tissues similar to those found in the diets (close to
$-19 \%$ ). To assess their turnover in tissues, birds of G1 received diets composed predominantly of $\mathrm{C}_{3}$ cycle plants (based on rice and soybean) shortly after accommodation, while birds of other groups remained predominantly fed with $\mathrm{C}_{4}$ diet (based on corn and soybeans). The diet of G2 was mainly replaced by $\mathrm{C}_{3}$ diet (based on rice and soybeans) on the 7th day of age. G3 started to receive $C_{3}$ diet on the 14th day of age, whereas the diet of G4 was replaced on the 21st, G5 on the 28th. In G6, the substitution occurred on the 35th day of age (Table 2).

\subsection{Sample collection and preparation}

Weekly replacement of the diet allowed the evaluation of tissue turnover during several stages of bird growth, since broiler metabolism differs with age, being faster at the beginning due to the full exchange of isotopic signals in the first week of life that may occur according to the tissue analyzed. The first collection of each group was always performed prior to the exchange of the diets to detect the baseline isotopic signal of the tissues. The collection time of each group was estimated, due to the decrease of metabolism with advancing age, to allow the total isotopic signal exchange of the analyzed tissues. During collection days, six birds per group were randomly selected and sacrificed by cervical dislocation, and each bird was considered a repetition. Blood samples, blood plasma, pectoral muscle, keel, tibia, leg muscle (thigh/ drumstick complex), intestinal mucosa, and wing feathers were harvested.

Five-centimeter thick slices of the pectoral muscle were obtained from $5 \mathrm{~cm}$ from the longitudinal middle third of left Pectoralis major. To obtain keel samples, the cartilaginous extension was removed from the sternum and the bone insertion was trimmed by a transversal cut, forming a right angle with its dorsal surface. Leg muscle samples were taken from the more lateral peroneal iliotibial. Tibial bone samples were obtained from the longitudinal middle third of the left tibia, excluding spinal content through scraping and rinsing with distilled water. Mucosal samples were collected from small intestine (in the duodenum) by means of scraping with a glass cover slip. Blood samples were collected in 1-mL plastic tubes and in test tubes pre-treated with heparin, which were subsequently centrifuged to obtain plasma. Feather samples were taken from bird's wings. All samples were labeled accurately and immediately frozen at $-20^{\circ} \mathrm{C}$ until further use.

Sample preparation and isotope analyses were performed at the Centro de Isótopos Estáveis of Instituto de Biociências, UNESP, Botucatu Campus, São Paulo, Brazil. Samples of pectoral muscle, keel, tibia, leg muscle, and feather were thawed, washed in distilled water, and dried in a forced-ventilation oven (MA035, Marconi, Piracicaba, Brazil) at $55^{\circ} \mathrm{C}$ for $48 \mathrm{~h}$. Samples of blood, plasma, and mucosa were thawed and dried under a vacuum for $48 \mathrm{~h}$ in a lyophilizer (L108, Liotop, São Carlos, Brazil). Approximately $2.0 \mathrm{~g}$ each of the pectoral muscle, keel, tibia, and leg muscles samples, and each experimental diet was ground using a cryogenic mill $(2010$ Geno/Grinder, SPEX SamplePrep, Metuchen, USA) at $-196^{\circ} \mathrm{C}$ for $3 \mathrm{~min}$ to obtain homogeneous material with fine granulometry (less than $60 \mu \mathrm{m}$ ), which were packed in plastic tubes as previously identified.

\subsection{Isotopic and analytical measurements}

Approximately 50-70 $\mu$ g of samples were weighed and packed into tin capsules, and introduced by means of an automatic viewer in an elemental analyzer (Flash 2000 Organic Elemental Analyzer, Thermo Fisher Scientific, Waltham, USA) for isotope ratio mass spectrometer (IRMS), in which, oxygen (O2) and copper oxide (CuO) were reacted to obtain $\mathrm{CO} 2$. The gases formed were separated in a gas chromatographic column and analyzed by mass-spectrometry of isotope ratios (Delta V Isotope Ratio Mass Spectrometer, Thermo Fisher Scientific, Waltham, USA).

The values of isotope ratios were expressed in delta $\left(\delta^{13} \mathrm{C}\right)$ relative to PeeDee Belemnite (PDB) international standard with an analysis 
Table 1

Percentage composition, calculated nutritional levels, and average isotopic values analyzed in diets.

\begin{tabular}{|c|c|c|c|c|c|c|c|c|}
\hline & \multicolumn{8}{|l|}{ Diets } \\
\hline & \multicolumn{2}{|c|}{ Pre-Starter } & \multicolumn{2}{|l|}{ Starter } & \multicolumn{2}{|l|}{ Grower } & \multirow{2}{*}{$\begin{array}{l}\text { Finisher } 1 \\
\text { C3 }\end{array}$} & \multirow{2}{*}{$\begin{array}{l}\text { Finisher } 2 \\
\text { C3 }\end{array}$} \\
\hline & $\mathrm{C} 4$ & $\mathrm{C} 3$ & $\mathrm{C} 4$ & $\mathrm{C} 3$ & $\mathrm{C} 4$ & $\mathrm{C} 3$ & & \\
\hline \multicolumn{9}{|l|}{ Ingredients (\%) } \\
\hline Corn ground & 54.92 & 0.00 & 55.84 & 0.54 & 56.75 & 1.25 & 1.90 & 2.40 \\
\hline Rice grits & 0.00 & 54.73 & 3.27 & 58.37 & 5.00 & 60.28 & 64.25 & 65.50 \\
\hline Soybean meal (45\% CP) & 38.53 & 37.76 & 34.91 & 34.14 & 31.64 & 30.87 & 26.61 & 24.51 \\
\hline Soybean oil & 2.28 & 3.18 & 2.27 & 3.18 & 3.28 & 4.19 & 4.10 & 5.01 \\
\hline Common salt & 0.51 & 0.51 & 0.49 & 0.49 & 0.47 & 0.47 & 0.45 & 0.41 \\
\hline Vit. and min. supl. ${ }^{\mathrm{a}}$ & 0.33 & 0.33 & 0.33 & 0.33 & 0.33 & 0.33 & 0.33 & 0.33 \\
\hline Calcite limestone (Ca 37.7\%) & 0.92 & 0.81 & 0.92 & 0.83 & 0.86 & 0.76 & 0.66 & 0.60 \\
\hline Dicalcium phosphate (Ca $24.5 \%$, P $18.5 \%$ ) & 1.91 & 2.05 & 1.52 & 1.65 & 1.29 & 1.43 & 1.23 & 1.03 \\
\hline DL-Methionine $(99.2 \%)$ & 0.22 & 0.22 & 0.18 & 0.18 & 0.17 & 0.16 & 0.15 & 0.08 \\
\hline L-Lysine (78\%) & 0.28 & 0.27 & 0.22 & 0.20 & 0.19 & 0.18 & 0.22 & 0.11 \\
\hline L-Threonine (98\%) & 0.11 & 0.15 & 0.06 & 0.11 & 0.05 & 0.09 & 0.11 & 0.04 \\
\hline \multicolumn{9}{|l|}{ Nutritional levels (\%) } \\
\hline EM (MJ/kg) & 12.35 & 12.35 & 12.56 & 12.56 & 12.98 & 12.98 & 13.19 & 13.52 \\
\hline Crude protein & 22.20 & 22.20 & 20.80 & 20.80 & 19.50 & 19.00 & 18.00 & 17.00 \\
\hline Calcium & 0.92 & 0.92 & 0.82 & 0.82 & 0.73 & 0.74 & 0.64 & 0.56 \\
\hline Available phosphorous & 0.47 & 0.47 & 0.39 & 0.39 & 0.34 & 0.35 & 0.30 & 0.26 \\
\hline Methionine & 0.51 & 0.51 & 0.46 & 0.46 & 0.43 & 0.43 & 0.41 & 0.32 \\
\hline Methionine + cystine & 0.81 & 0.78 & 0.74 & 0.71 & 0.70 & 0.67 & 0.62 & 0.53 \\
\hline Lysine & 1.31 & 1.31 & 1.18 & 1.17 & 1.08 & 1.08 & 1.01 & 0.87 \\
\hline Threonine & 0.86 & 0.85 & 0.76 & 0.77 & 0.70 & 0.70 & 0.66 & 0.56 \\
\hline Sodium & 0.22 & 0.22 & 0.21 & 0.21 & 0.20 & 0.20 & 0.20 & 0.18 \\
\hline Chlorine & 0.35 & 0.34 & 0.34 & 0.33 & 0.33 & 0.32 & 0.31 & 0.28 \\
\hline$\delta^{13} \mathrm{C}(\% 0)$ & -19.84 & -28.79 & -19.20 & -28.78 & -18.52 & -28.27 & -28.52 & -28.68 \\
\hline
\end{tabular}

${ }^{a}$ Vitamin and mineral Vaccinar ${ }^{\circledR}$ Supplement (per kg of food): Pre-starting Phase -:1.50 mg folic acid; $14.00 \mathrm{mg}$ pantothenic acid; $0.08 \mathrm{mg}$ biotin; $8.00 \mathrm{mg}$ copper; $0.35 \mathrm{~g}$ choline;

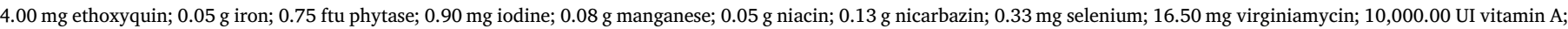

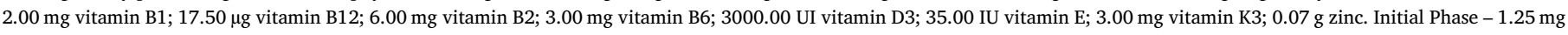

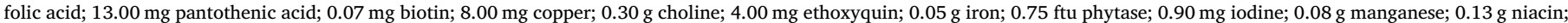

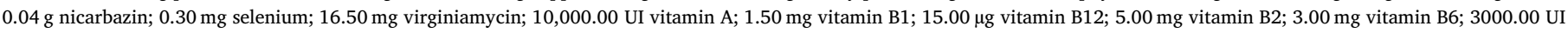

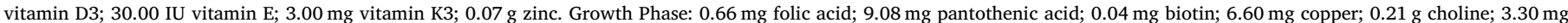

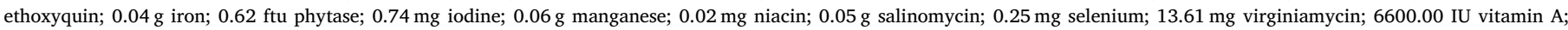

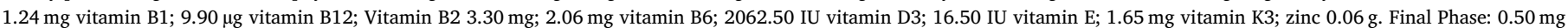

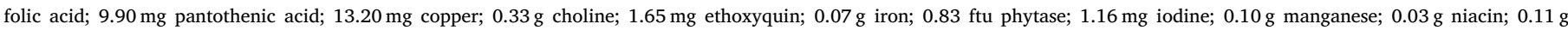

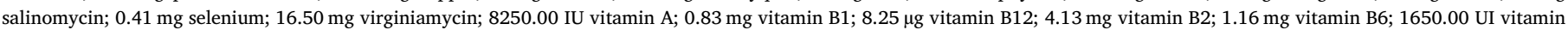
D3; 16.50 IU vitamin E; $2.48 \mathrm{mg}$ Vitamin K3; $0.10 \mathrm{~g}$ zinc.

Table 2

Distribution of experimental groups.

\begin{tabular}{lll}
\hline Groups & $\begin{array}{l}\text { Diets replacement } \\
\text { (age in days) }\end{array}$ & $\begin{array}{l}\text { Birds age in days at the moment of tissues } \\
\text { collection }\end{array}$ \\
\hline G1 $(0-21)$ & $0^{\text {a }}$ & $0 ; 0.5 ; 1 ; 1.5 ; 2 ; 3 ; 5 ; 7 ; 9 ; 11 ; 14 ; 17 ; 21$ \\
G2 (7-28) & 7 & $7 ; 8 ; 11 ; 13 ; 15 ; 17 ; 19 ; 21 ; 24 ; 28$ \\
G3 (14-35) & 14 & $14 ; 15 ; 17 ; 19 ; 21 ; 24 ; 27 ; 30 ; 33 ; 35$ \\
G4 (21-42) & 21 & $21 ; 22 ; 24 ; 26 ; 28 ; 30 ; 33 ; 36 ; 39 ; 42$ \\
G5 (28-77) & 28 & $28 ; 29 ; 31 ; 33 ; 36 ; 39 ; 42 ; 49 ; 56 ; 63 ; 77$ \\
G6 (35-98) & 35 & $35 ; 36 ; 37 ; 39 ; 42 ; 45 ; 49 ; 56 ; 63 ; 70 ; 84 ; 98$ \\
\hline
\end{tabular}

${ }^{\text {a }}$ Day $0=$ the time of housing of broilers chicks.

error of about $0.2 \%$, calculated by equation $\delta^{13} \mathrm{C}_{\text {(sample, standard) }}=$ $\left[\left(\mathrm{R}_{\text {sample }} / \mathrm{R}_{\text {standard }}\right)-1\right] \times 10^{3}$, where $\delta^{13} \mathrm{C}$ is the relative enrichment of ${ }^{13} \mathrm{C} /{ }^{12} \mathrm{C}$ ratio of the sample when compared to PDB standard, and $\mathrm{R}$ is isotopic ratio $\left({ }^{13} \mathrm{C} /{ }^{12} \mathrm{C}\right)$ of standard and sample (Brand, 1996).

To measure quantitatively the speed of carbon replacement in birds tissues by the diet, during each evaluated period, exponential data adjustment $\left(\delta^{13} \mathrm{C}\right)$ was carried out using the method of first-order exponential regression expressed by equation $\delta^{13} \mathrm{C}(\mathrm{t})=\delta^{13} \mathrm{C}(\mathrm{f})+$ $\left[\delta^{13} \mathrm{C}(\mathrm{i})-\delta^{13} \mathrm{C}(\mathrm{f})\right] \mathrm{e}^{-\mathrm{kt}}$, where $\delta^{13} \mathrm{C}(\mathrm{t})$ is tissue isotopic enrichment at any time (t), $\delta^{13} \mathrm{C}(\mathrm{f})$ is tissue isotopic enrichment at balance level or final condition, $\delta^{13} \mathrm{C}(\mathrm{i})$ is tissue isotopic enrichment in the starting condition, $\mathrm{k}$ is exchange constant (turnover) in units of time $\mathrm{e}^{-1}$ and $\mathrm{t}$ is the time (in days) since food replacement (Ducatti et al., 2002), calculated by Minitab 16 software.
By obtaining the exchange constant $(\mathrm{k})$ value by exponential adjustment, it is possible to calculate the total fraction of exchanged ${ }^{13} \mathrm{C}$ atoms (F) within the experimental period, and the half-life (T) provided in the condition of $50 \%$ exchange. To ensure that the results are reliable, tissues should reach equilibrium (more than $95 \%$ of ${ }^{13} \mathrm{C}$ tissue atoms should be replaced by those present in the diet). To determine the fraction of atoms exchanged during the period analyzed, we used equation $\mathrm{F}=1-\mathrm{e}^{-\mathrm{kt}}$, where $\mathrm{F}$ is the fraction of atoms exchanged, $\mathrm{k}$ is the constant exchange (turnover) in units of time $\mathrm{e}^{-1}$ and $\mathrm{t}$ is the time (in days) since food replacement. The half-life of ${ }^{13} \mathrm{C}$ for the tissues studied, in the condition of $50 \%$ was calculated by the equation $\mathrm{T}=\ln 2 / \mathrm{k}$, where $\mathrm{T}$ is the half-life, in time (days), $\ln$ is neperian logarithm, $\mathrm{k}$ is the constant turnover in tissue, expressed in day ${ }^{-1}$ (Ducatti et al., 2002).

\section{Results}

\subsection{Incorporation of dietary carbon into tissues}

$\mathrm{C}_{3}$ (based on rice and soybean) and $\mathrm{C}_{4}$ (based on corn and soybeans) diets showed average $\delta^{13} \mathrm{C}$ values equal to $-28.61 \%$ and $-19.18 \%$, respectively (Table 1). The enrichment of $\mathrm{C}_{4}$ diets is a consequence of corn predominance, which has a higher proportion of ${ }^{13} \mathrm{C}$ in relation to rice. The change in $\delta^{13} \mathrm{C}$ value of tissues, over time, gradually occurred during bird growth and development, reaching values close to those present in the diets (Table 3), with minor differences related to isotopic fractionation (Table 4). Fig. 1 illustrates isotopic dilution (carbon incorporation from the diet into tissues) in the pectoral muscle, keel, 
Table 3

Average values of $\delta^{13} \mathrm{C}(\%)$ in broiler tissues at the beginning and end of each group period.

\begin{tabular}{|c|c|c|c|c|c|c|c|c|}
\hline Groups & Pectoral muscle & Keel & Tibia & Leg muscle & Intestinal mucosa & Blood plasma & Blood & Wing feathers \\
\hline G1 (0 days) & $-18.89 \pm 0.19$ & $-18.95 \pm 0.50$ & $-16.84 \pm 0.19$ & $-19.22 \pm 0.18$ & $-19.49 \pm 0.31$ & $-19.04 \pm 0.34$ & $-19.46 \pm 0.19$ & $-18.34 \pm 0.11$ \\
\hline G1 (21 days) & $-26.50 \pm 0.15$ & $-26.35 \pm 0.15$ & $-24.76 \pm 0.29$ & $-27.17 \pm 0.40$ & $-28.32 \pm 0.18$ & $-27.20 \pm 0.07$ & $-27.00 \pm 0.14$ & $-25.54 \pm 0.12$ \\
\hline G2 (7 days) & $-19.72 \pm 0.19$ & $-18.45 \pm 0.38$ & $-17.76 \pm 0.30$ & $-20.57 \pm 0.60$ & $-21.60 \pm 0.13$ & $-18,97 \pm 0.24$ & $-20.52 \pm 0.31$ & $-19.34 \pm 0.10$ \\
\hline G2 (28 days) & $-26.04 \pm 0.29$ & $-25.84 \pm 0.08$ & $-24.72 \pm 0.19$ & $-26.60 \pm 0.28$ & $-28.14 \pm 0.13$ & $-27.29 \pm 0.12$ & $-26.93 \pm 0.10$ & $-25.02 \pm 0.22$ \\
\hline G3 (14 days) & $-20.10 \pm 0.18$ & $-18.13 \pm 0.17$ & $-17.80 \pm 0,18$ & $-20.72 \pm 0.18$ & $-22.20 \pm 0.10$ & $-19.55 \pm 0.24$ & $-21.19 \pm 0.15$ & $-19.62 \pm 0.17$ \\
\hline G3 (35 days) & $-25.88 \pm 0.12$ & $-25.25 \pm 0.08$ & $-24.04 \pm 0,13$ & $-25.94 \pm 0.41$ & $-27.87 \pm 0.12$ & $-26.79 \pm 0.15$ & $-26.38 \pm 0.19$ & $-24.25 \pm 0.46$ \\
\hline G4 (21 days) & $-20.22 \pm 0.05$ & $-18.24 \pm 0.21$ & $-17.61 \pm 0.25$ & $-19.90 \pm 0.32$ & $-22.08 \pm 0.17$ & $-19.58 \pm 0.15$ & $-21.48 \pm 0.08$ & $-20.65 \pm 0.14$ \\
\hline G4 (42 days) & $-25.38 \pm 0.15$ & $-24.20 \pm 0.11$ & $-24.04 \pm 0,16$ & $-26.25 \pm 0.30$ & $-27.77 \pm 0.13$ & $-26.71 \pm 0.15$ & $-26.22 \pm 0.15$ & $-23.93 \pm 0.45$ \\
\hline G5 (28 days) & $-19.65 \pm 0.11$ & $-17.55 \pm 0.30$ & $-17.16 \pm 0.15$ & $-20.25 \pm 0.19$ & $-22.43 \pm 0.24$ & $-19.75 \pm 0.19$ & $-21.18 \pm 0.07$ & $-19.19 \pm 0.16$ \\
\hline G5 (77 days) & $-26.58 \pm 0.21$ & $-25.00 \pm 0.19$ & $-24.41 \pm 0.06$ & $-26.76 \pm 0.27$ & $-27.92 \pm 0.21$ & $-26.42 \pm 0.24$ & $-26.65 \pm 0.12$ & $-23.78 \pm 0.33$ \\
\hline G6 (35 days) & $-20.50 \pm 0.19$ & $-18.25 \pm 0.26$ & $-17.50 \pm 0.23$ & $-20.57 \pm 0,18$ & $-22.92 \pm 0.14$ & $-19.77 \pm 0.18$ & $-21.18 \pm 0.19$ & $-18.69 \pm 0.15$ \\
\hline G6 (98 days) & $-26.42 \pm 0.27$ & $-24.83 \pm 0.01$ & $-24.50 \pm 0.09$ & $-26.71 \pm 0.53$ & $-28.00 \pm 0.24$ & $-26.27 \pm 0.28$ & $-26.62 \pm 0.18$ & $-22.35 \pm 0.90$ \\
\hline
\end{tabular}

tibia, leg muscle, intestinal mucosa, plasma, blood, and feathers.

\subsection{Atom fraction exchanged in the experimental period evaluated and half-life calculation}

Tables 5, 6 present the fractions of exchanged atoms and half-life values, respectively, referring to each period. Exponential equations as a function of time, and determination coefficients are presented in S1 to S8 supplementary tables.

\section{Discussion}

This study estimated the metabolic rate via carbon turnover of broiler tissues by assessing carbon turnover in different growth phases by using stable isotope technique, and by evaluating the natural changes in Carbon-13 $\left({ }^{13} \mathrm{C}\right)$ between $\mathrm{C}_{3}$ and $\mathrm{C}_{4}$ cycle plants. Values of incorporation of dietary carbon into tissues show that fractionation occurs differently between the assessed tissues and development phases. A small change in fractionation between developmental phases was observed in the same tissue, although values remained similar, emphasizing differences between tissues. Isotopic variation between tissues may reflect their different biochemical composition (proteins, carbohydrates, lipids). DeNiro and Epstein (1978) showed that these biochemical fractions have distinct isotopic signals, suggesting that the amendments stem from numerous metabolic pathways that permit the conversion of a carbon isotope from one biochemical fraction to another. Therefore, differences in fractionation values are related to the chemical composition of each tissue.

Pectoral muscle, keel, tibia, leg muscle, blood plasma, blood, and wing feathers suffered major fractionation, suggesting that these tissues underwent distinct metabolic processes until their formation. These tissues receive nutrients that are transported through the bloodstream, and can derive from diet and/or catabolism of other tissues and interfere with the final isotopic value of the developing tissue or its turnover. In turn, the intestinal mucosa presented a low fractionation value (less than $1 \%$ ) that might be explained by the local nutritional status of the intestinal mucosa (Maiorka et al., 2002), i.e., direct digestion and absorption of nutrients by enterocytes (intestinal absorptive cells), which results in an isotopic signal that is similar to that of the current diet. The assertion of DeNiro and Epstein (1978), that an animal is isotopically what it eats with variation around $\pm 2 \%$ or for $13 \mathrm{C}$ refers to the whole animal. In case of broiler chickens, this variation applies to most tissues; however, this was much higher (more than 4\%o) for tibia and less than $1 \%$ for mucosa, as illustrated in Table 4.

During the experimental period, the tissues reached isotopic equilibrium (more than 95\% of exchanged carbon atoms) in almost all groups examined, with the exception of the tibia in G4 (87\% of exchange), leg muscle in G4 (91\%), blood in G3 and G4 (93\% and 85\% of exchange, respectively), and feathers in G4 and G6 (94\% and 79\%) (Table 5). It is worth noting that half-life values in birds increase with age, as the growth rate (prevalence of synthesis rate over degradation rate) is higher in young animals (Gonzales and Sartori, 2002). A similar age-related increase in half-life values was observed by Ducatti et al. (2014) assessing the turnover of ${ }^{13} \mathrm{C}$ in pectoral muscle, keel, tibia, and liver.

New and newly formed tissue acquires carbon from the diets, whereas older tissue contains carbon from old diets until complete turnover. When the synthesis rate is higher than the degradation rate, the isotopic signal exchange increases. With age, the difference between anabolic and catabolic processes decreases and the bird's tissues stop growing. At this stage only tissue turnover exists, a phenomenon whereby synthesis and degradation occur at the same time (Gonzales and Sartori, 2002). Consequently, the speed of carbon exchange (change in tissue isotopic values) decreases and the half-life increases, i.e., the time taken for replacement of tissue carbon by dietary carbon increases until it becomes constant. Based on the results of this study it is assumed that, for the age evaluated, birds continued growing, i.e., they exhibited a higher anabolic than catabolic rate, as half-life values continued to rise.

It is worth to noting that keel and pectoral muscle presented an increased half-life from G1 to G4 (21-42 days of age), which is expected to participate in the support structure of pectoral muscle, i.e., the phase of greater muscle growth. From the evaluated period in G5, the keel continued to exhibit slower exchange, which can be explained by it being a tissue with diminished growth before developing into muscle tissue, thus beginning the process of calcification (Gonzales and Sartori,

Table 4

Isotopic fraction factor $(\%)$ between broiler tissues and diet $\left(\Delta=\delta_{\text {tissue }}-\delta_{\text {diet }}\right)$ at the end of each group period.

\begin{tabular}{|c|c|c|c|c|c|c|c|c|}
\hline Group & Pectoral muscle & Keel & Tibia & Leg muscle & Intestinal mucosa & Blood plasma & Blood & Wing feathers \\
\hline G1 (0-21) & 2.28 & 2.43 & 4.02 & 1.61 & 0.46 & 1.58 & 1.78 & 3.24 \\
\hline G2 (7-28) & 2.75 & 2.94 & 4.06 & 2.18 & 0.64 & 1.49 & 1.85 & 3.76 \\
\hline G3 (14-35) & 2.39 & 3.02 & 4.23 & 2.33 & 0.40 & 1.48 & 1.89 & 4.02 \\
\hline G4 (21-42) & 3.14 & 4.32 & 4.48 & 2.27 & 0.75 & 1.81 & 2.30 & 4.59 \\
\hline G5 (28-77) & 2.10 & 3.68 & 4.27 & 1.92 & 0.76 & 2.26 & 2.03 & 4.90 \\
\hline G6 (35-98) & 2.26 & 3.85 & 4.18 & 1.97 & 0.68 & 2.41 & 2.06 & 6.33 \\
\hline Average & $2.49 \pm 0.39$ & $3.37 \pm 0.69$ & $4.2 \pm 0.16$ & $2.05 \pm 0.27$ & $0.62 \pm 0.15$ & $1.84 \pm 0.41$ & $1.99 \pm 0.19$ & $4.47 \pm 1.08$ \\
\hline
\end{tabular}



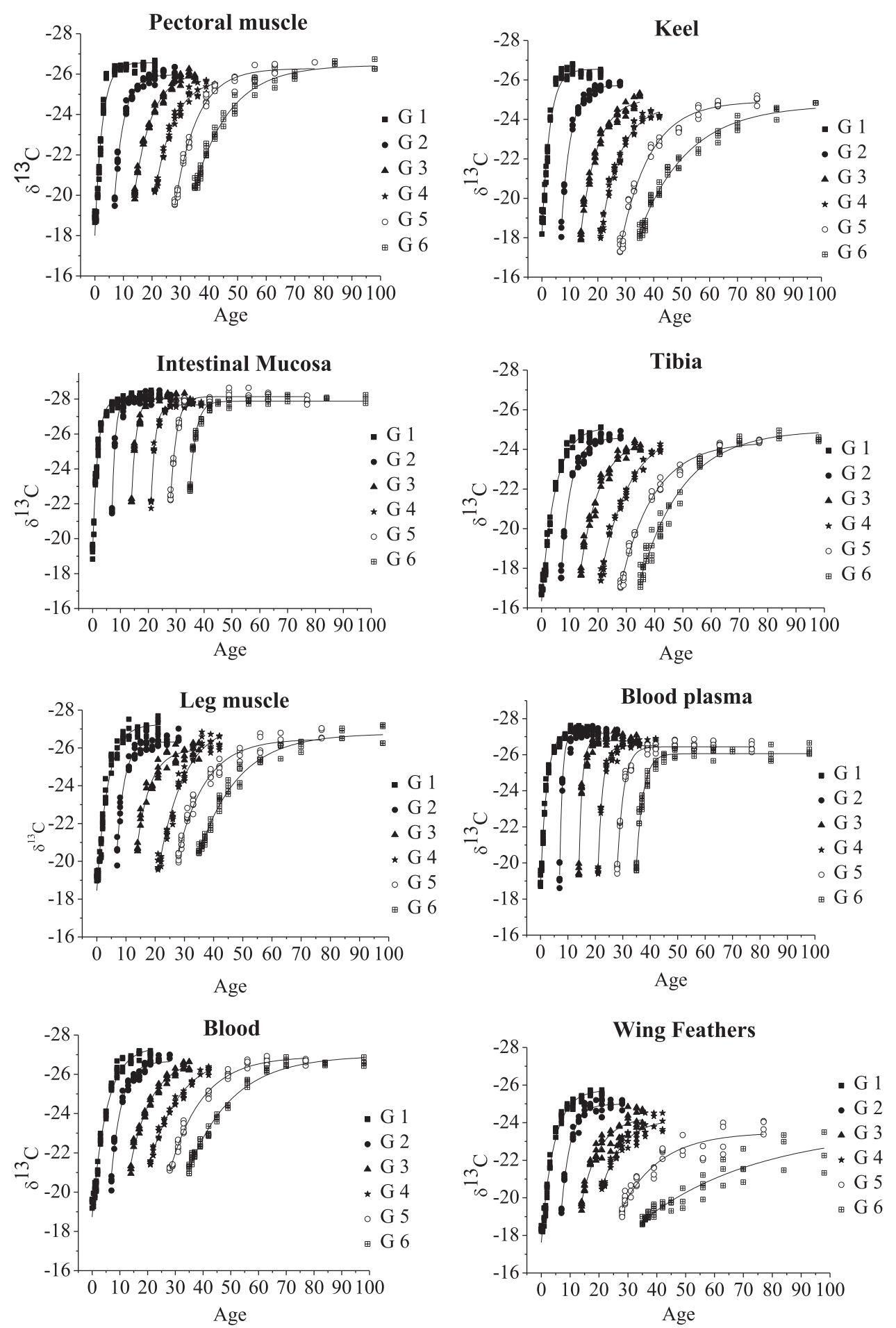

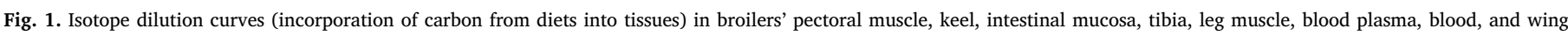
feathers.

Table 5

Fraction of exchanged atoms (F, \%) of broiler tissues over the assessed period.

\begin{tabular}{|c|c|c|c|c|c|c|c|c|}
\hline Groups & Pectoral muscle & Keel & Tibia & Leg muscle & Intestinal mucosa & Blood plasma & Blood & Wing feathers \\
\hline G1 (0-21) & 99.97 & 99.95 & 98.75 & 99.62 & 99.99 & 99.99 & 98.20 & 99.21 \\
\hline G2 (7-28) & 99.84 & 99.82 & 99.78 & 99.98 & 99.99 & 99.99 & 99.62 & 99.96 \\
\hline G3 (14-35) & 96.72 & 97.20 & 95.47 & 99.00 & 99.99 & 99.99 & 92.95 & 96.26 \\
\hline G4 (21-42) & 96.03 & 94.76 & 87.44 & 90.91 & 99.99 & 99.99 & 84.67 & 94.47 \\
\hline G5 (28-77) & 99,81 & 99.02 & 98.41 & 99.40 & 99.99 & 99.99 & 98.67 & 97.39 \\
\hline G6 (35-98) & 99,51 & 97.17 & 98.30 & 99.03 & 100.00 & 100.00 & 98.06 & 78.50 \\
\hline
\end{tabular}


Table 6

Half-life ( $\mathrm{T}$, days) of carbon in broiler tissue calculated after exponential data adjustment and their respective determination coefficients ( $\mathrm{r}^{2}$ ).

\begin{tabular}{|c|c|c|c|c|c|c|c|c|c|c|c|c|c|c|c|c|}
\hline Groups & Pectoral muscle & $\mathrm{r}^{2}$ & Keel & $r^{2}$ & Tibia & $\mathrm{r}^{2}$ & Leg muscle & $\mathrm{r}^{2}$ & Intestinal mucosa & $r^{2}$ & Blood plasma & $r^{2}$ & Blood & $\mathrm{r}^{2}$ & Wing feathers & $\mathrm{r}^{2}$ \\
\hline G1 (0-21) & 1.78 & 0.96 & 1.91 & 0.98 & 3.32 & 0.99 & 2.61 & 0.98 & 1.25 & 0.98 & 1.57 & 0.98 & 3.63 & 0.98 & 3.01 & 0.98 \\
\hline G2 (7-28) & 2.27 & 0.98 & 2.31 & 0.98 & 2.37 & 0.99 & 1.87 & 0.96 & 0.8 & 0.98 & 0.64 & 0.99 & 2.61 & 0.98 & 1.84 & 0.97 \\
\hline G3 (14-35) & 4.26 & 0.99 & 4.07 & 0.98 & 4.7 & 0.96 & 3.16 & 0.95 & 1.19 & 0.98 & 0.79 & 0.98 & 5.49 & 0.98 & 4.43 & 0.92 \\
\hline G4 (21-42) & 4.51 & 0,98 & 4.93 & 0.98 & 7.02 & 0.98 & 6.07 & 0.97 & 1.05 & 0.99 & 1.13 & 0.99 & 7.76 & 0.99 & 5.03 & 0.92 \\
\hline G5 (28-77) & 5.42 & 0.99 & 7.34 & 0.98 & 8.19 & 0.99 & 6.65 & 0.97 & 1.58 & 0.99 & 1.64 & 0.99 & 7.85 & 0.99 & 9.32 & 0.90 \\
\hline G6 (35-98) & 8.2 & 0.98 & 12.24 & 0.98 & 10.71 & 0.98 & 9.43 & 0.98 & 1.51 & 0.98 & 1.71 & 0.97 & 11.07 & 0.99 & 28.41 & 0.92 \\
\hline
\end{tabular}

\section{2).}

Tibia, leg muscle, intestinal mucosa, blood plasma, blood, and wing feathers showed faster exchange rate in G2 when compared with all groups, including G1. At this stage, there was an emphasis on the rate of bone growth and it seems that the nutritional demand increased, thus accelerating the development of the intestinal mucosa (area in which digestion and nutrient absorption occurs). In this period, faster exchange in feathers is possibly due to their replacement, which occurs around the 14th day of age and accelerates the metabolism of this tissue. The faster metabolic rate of blood plasma and blood during this period may be due to their role in transporting nutrients, hormones, and antibodies to all other animal tissues.

In this study, the carbon half-life differed between tissues; blood plasma and intestinal mucosa presented a faster metabolic rate, that in breast and leg muscle was intermediate, and keel, tibia, and wing feathers was slow. Differences also occurred with age, and in all tissue, the metabolic rate was higher in younger animals when compared to old broilers in which the rate was slower. Although there was an agedependent increase in half-life, the blood plasma and intestinal mucosa, unlike other tissues, was less affected when compared to tissues with high metabolic rates across all periods analyzed.

As the tibia and feathers have a slow metabolism, they required longer times for isotopic signal exchange. In this study, the evaluation period of all tissues was extended from G5 (the group that began to exchange signals at 28-days of age) as a consequence of reduced metabolism in the body with advancing age. However, for bone tissue and feathers, the evaluation days should have been prolonged from G4, since these groups did not reach homeostasis. As for feathers, even extending the G6 period was not sufficient to reach the equilibrium. Therefore, the half-life values calculated for those tissues that failed to reach isotopic homeostasis may not be reliable.

As for blood, it was expected that the exchange rate would be faster since cells are circulating; this was followed by that for the intestinal mucosa, which also receives dietary nutrients. It was noted that the time of isotopic exchange increased to a greater extent from G3 in these tissues than in other tissues. An explanation for this result may rely on the fact that in addition to dietary nutrients, the blood also transports nutrients from other tissues following catabolism in response to their nutritional requirements during the growth phase. Such nutrients may exhibit isotopic values that differ from those of the diet and interfere with the blood velocity of isotopic value exchange. Another explanation would be that blood cells present a longer average lifespan, around 28-35 days (Macari and Luquetti, 2002), and as such retain the isotopic signal of past diets, which may interfere with the signal of blood as a whole.

\section{Conclusions}

Isotopic fractionation may be observed in tissues (difference between tissue $\delta$ and that of the diet $\delta$ ), with the largest fractionation occurring in tibia and feathers with a difference of more than $4 \%$. The smallest fractionations occur in the mucosa and the difference is less than $1 \%$. Plasma, pectoral muscle, keel and intestinal mucosa present a higher metabolic rate in the first week of the broiler's life, with very similar half-live values. The metabolic rate in younger animals is higher than in older animals. The metabolic rate of chest, keel, tibia, leg muscle, and feather tissue decrease with advancing age. In the first and second week of the broiler's life, pectoral muscle, keel, mucosa, and plasma can provide information of recent diets, while tibia, leg muscle, blood, and feathers can provide information of past diets. From the third week, in addition to tibia, leg muscle, blood and feathers, pectoral muscle, and keel can provide information related to older diets. Due to the fast metabolic rate throughout the animal's life, mucosa and plasma will provide information relating to recent diets. Feathers, blood, and plasma are an interesting option, since they are tissues that can be collected at any stage of a birds' growth, without the need for sacrificing the animal. Due to blood cells having a long average lifespan, blood can be used to identify older diets depending on the animal's life stage. However, as this may be affected by interference from isotopic values of diet and nutrients derived from the catabolism of other tissues, which will depend on the animal's physiological condition, blood should be used with caution in traceability studies. Nevertheless, blood plasma and intestinal mucosa are interesting tissues for use in the study feed traceability of recent diets at all stages of a broiler's life.

\section{Acknowledgments}

The authors would like to thank the Fundação de Amparo à Pesquisa do Estado de São Paulo - FAPESP by granting scholarship (process 2011/17406-4), and aid for research (process 2008/57411-4). Thanks to Vaccinar Nutrição e Saúde Animal for the donation of the vitamin and mineral supplements.

\section{Appendix A. Supporting information}

Supplementary data associated with this article can be found in the online version at http://dx.doi.org/10.1016/j.livsci.2018.01.019.

\section{References}

Ayliffe, L.K., Cerling, T.E., Robinson, T., West, A.G., Sponheimer, M., Passey, B.H., Hammer, J., Roeder, B., Dearing, M.D., Ehleringer, J.R., 2004. Turnover of carbon isotopes in tail hair and breath $\mathrm{CO}_{2}$ of horses fed an isotopically varied diet. Oecologia 139, 11-12.

Boutton, T.W., Smith, B.N., Harrison, A.T., 1980. Carbon isotope ratios and crop analyses of Arphia (Orthoptera: acrididae) species in southeastern Wyoming grassland. Oecologia 45, 299-306.

Brand, W.A., 1996. High precision isotope ratio monitoring techniques in mass spectrometry. J. Mass Spectrom. 31, 225-235.

Bricout, J., Koziet, J., 1987. Control of the authenticity of orange juice by isotopic analysis. J. Agric. Food Chem. 35, 758-760.

Brookes, S.T., Barrie, A., Davies, J.E., 1991. A rapid 13C/12C test for determination of corn-syrups in honey. J. AOAC Int. 74, 627-629.

Buchheister, A., Latour, R.J., 2010. Turnover and fractionation of carbon and nitrogen stable isotopes in tissues of a migratory coastal predator, summer flounder (Paralichthys dentatus). Can. J. Fish. Aquat. Sci. 67, 445-461.

Carrijo, A.S., Pezzato, A.C., Ducatti, C., Sartori, J.R., Trinca, L., Silva, E.T., 2006. Traceability of bovine meat and bone meal in poultry by stable isotope analysis. Braz. J. Poult. Sci. 8, 63-68.

Denadai, J.C., Ducatti, C., Sartori, J.R., Pezzato, A.C., Móri, C., Gottmann, R., Mituo, M.A.O., Bordinhon, A.M., 2008. The traceability of animal meals in layer diets as detected by stable carbon and nitrogen isotope analyses of eggs. Braz. J. Poult. Sci. 10, 189-194.

DeNiro, M.J., Epstein, S., 1978. Influence of diet on the distribution of carbon isotopes in animals. Geochim. Cosmochim. Acta 42, 495-506.

Ducatti, C., Carrijo, A.S., Pezzato, A.C., Mancera, P.F.A., 2002. Modelo teórico e 
experimental da reciclagem do carbono-13 em tecidos de mamíferos e aves. Sci. Agric. 59, 29-33.

Ducatti, C., Mituo, M.A.O., Denadai, J.C., Buosi, M.M., Souza-Kruliski, C.R., Pelícia, V.C., Sartori, J.R., 2014. Turnover do carbono nos tecidos de frangos de corte me diferentes fases de crescimento. Cienc. Rural 44, 1472-1478.

Gannes, L.Z., Del Rio, C.M., Koch, P., 1998. Natural abundance variations in stable isotopes and their potential use in animal physiological ecology. Comp. Biochem. Physiol. A Mol. Integr. Physiol. 119, 725-737.

Gonzales, E., Sartori, J.R., 2002. Crescimento e metabolismo muscular. In: Macari, M., Furlan, R.L., Gonzales, E. (Eds.), Fisiologia Aviária Aplicada a Frangos de Corte, 2nd ed. FUNEP/UNESP, Jaboticabal, SP, pp. 279-297.

Hobson, K.A., 1995. Reconstructing avian diets using stable-carbon and nitrogen isotope analysis of egg components: patterns of isotopic fractionation and turnover. Condor 97, 752-762.

Hobson, K.A., Bairlein, F., 2003. Isotopic fractionation and turnover incaptive garden warblers (Sylvia borin): implications for de-lineating dietary and migratory associations in wild passerines. Can. J. Zool. 81, 1630-1635.

Hobson, K.A., Clark, R.G., 1992. Assessing avian diets using stable isotopes II: factors influencing diet-tissue fractionation. Condor 94, 189-197.

Hobson, K.A., Clarke, R.G., 1993. Turnover of ${ }^{13} \mathrm{C}$ in cellular and plasma fractions of blood: implications for nondestructive sampling in avian dietary studies. Auk 110, 638-641.

Jones, R.J., Ludlow, M.M., Troughton, J.H., Blunt, C.G., 1979. Estimation of the proportion of C3 and C4 plant species in the diet of animals from the ratio of natural ${ }^{12} \mathrm{C}$ and ${ }^{13} \mathrm{C}$ isotopes in the faeces. J. Agric. Sci. 92, 91-100.

Koziet, J., 1993. Determination of carbon-13 content of sugars of fruit and vegetable juices. Anal. Chim. Acta 271, 31-38.

Macari, M., Luquetti, B.C., 2002. Fisiologia Cardiovascular. In: Macari, M., Furlan, R.L., Gonzales, E. (Eds.), Fisiologia Aviária Aplicada a Frangos de Corte, 2nd ed. FUNEP/ UNESP, Jaboticabal, SP, pp. 17-35.

Maiorka, A., Boleli, I.C., Macari, M., 2002. Desenvolvimento e reparo da mucosa intestinal. In: Macari, M., Furlan, R.L., Gonzales, E. (Eds.), Fisiologia Aviária Aplicada a Frangos de Corte, 2nd ed. FUNEP/UNESP, Jaboticabal, SP, pp. 113-123.

Manca, G., Camin, F., Coloru, G.C., Del Caro, A., Detentori, D., Franco, M.A., Versini, G., 2001. Characterization of the geographical origin of Pecorino Sardo cheese by casein stable isotope $\left({ }^{13} \mathrm{C} /{ }^{12} \mathrm{C}\right.$ and $\left.{ }^{15} \mathrm{~N} /{ }^{14} \mathrm{~N}\right)$ ratios and free amino acid ratios. J. Agric. Food Chem. 49, 1404-1409.

Martin, G.J., Guillou, C., Martin, M.L., Cabanis, M.T., Tep, X., Aerny, J., 1988. Natural factors of isotope fractionation and the characterization of wines. J. Agric. Food Chem. 36, 316-322.

O'Leary, M.H., 1981. Carbon isotope fractionation in plants. Phytochemistry 20 (553), 567.

Oliveira, R.P., Ducatti, C., Denadai, J.C., Pezzato, A.C., Cruz, V.C., Sartori, J.R., Carrijo, A.S., Caldara, F.R., 2010. Traceability of poultry offal meal in broiler feeding using isotopic analysis $(\delta 13 \mathrm{C}$ and $\delta 15 \mathrm{~N}$ ) of different tissues. Braz. J. Poult. Sci. 12, 13-20.

Oppel, S., Powell, A.N., 2010. Carbon isotope turnover in blood as a measure of arrival time in migratory birds using isotopically distinct environments. J. Ornithol. 151, 123-131.

Pelícia, V.C., Zavarize, K.C., Ducatti, C., Stradiotti, A.C., Pezzato, A.C., Araujo, P.C., Mituo, M.A.O., Madeira, L.A., Sartori, J.R., 2011. Nucleotídeos na dieta de frangos de corte e seus efeitos sobre taxa de turnover da mucosa intestinal antes e após lesões causadas por coccidiose. Cienc. Rural. 41, 1652-1659.

Rock, L., 2012. The use of stable isotope techniques in egg authentication schemes: a review. Trends Food Sci. Technol. 28, 62-68.

Rossmann, A., Haberhauer, G., Hölzl, S., Horn, P., Pichlmayer, F., Voerkelius, S., 2000. The potential of multielement stable isotope analysis for regional origin assgnment of butter. Eur. Food Res. Technol. 211, 32-40.

Rostagno, H.S., Albino, L.F.T., Donzele, J.L., Gomes, P.C., Oliveira, R.F., Lopes, D.C., Ferreira, A.S., Barreto, S.L.T., Euclides, R.F., 2011. Tabelas Brasileiras Para aves e Suínos: Composição de Alimentos e Exigências Nutricionais, 3rd ed. Universidade Federal de Viçosa, Viçosa, MG, Brasil.

Sernagiotto, E.R., Ducatti, C., Sartori, J.R., Stradiotti, A.C., Maruno, M.K., Araujo, P.C., Carvalho, F.B., Pezzato, A.C., 2013. The se of carbon and nitrogen stable isotopes for the detection of poultry offal meal in meat-type quail feeds. Braz. J. Poult. Sci. 15, 65-70.

Smith, B.N., Epstein, S., 1971. Two categories of ${ }^{13} \mathrm{C} /{ }^{12} \mathrm{C}$ ratios for higher plants. Plant Physiol. 47, 380-384.

Tieszen, L.L., Hein, D., Qvortrup, S.A., Troughton, J.H., Imbamba, S.K., 1979. Use of ${ }^{13} \mathrm{C}$ values to determine vegetation selectivity in East African herbivores. Oecologia 37, $351-359$.

Tieszen, L.L., Boutton, T.W., Tesdahl, K.G., Slade, N.A., 1983. Fractionation and turnover of stable carbon isotopes in animal tissues: implications for 13C analysis of diet. Oecologia 57, 32-37.

White, J.W., Winters, K., Martin, P., Rossmann, A., 1998. Stable carbon isotope ratio analysis of honey: validation of internal standard procedure for worldwide application. J. AOAC Int. 81, 610-619. 